\title{
“Love of Life” Versus “Love of Death”: A Frommian Perspective on Middle Passage*
}

\author{
JIA Yan-yan, CHEN Hou-liang \\ Shandong University of Finance and Economics, Shandong, China
}

\begin{abstract}
According to Fromm, the life instinct constitutes the primary potentiality in man, while the death instinct a secondary potentiality, and which of the two prevails depending crucially on the living conditions that the subject experiences during his or her childhood. Not limited to the individual level, Fromm's observation works on the collective level as well. Different environments foster different potentialities and lead to the formation of different cultures and ethics. A biophilic ethics treasures the value of love, peace, reciprocal altruism and unity of being, while a biophobic ethics is more addicted to hatred, violence, dualistic confrontation, and mutual destruction. Appling Fromm's theory to the interpretation of Charles Johnson's Middle Passage, readers can get a newly enlightened understanding of this award-winning masterpiece. Based on Fromm’s hypothesis about human nature, this article analyzes the representation of the confrontations between the biophobic ethics and the biophilic ethics in this novel, the former being embodied by Captain Falcon’s “syndrome of decay” which is also Johnson’s critical metaphor of Western civilization, while the latter embodied by the Allmuseri culture's "syndrome of growth" which represents Johnson's idealistic imagination of the sum of non-Western civilization.
\end{abstract}

Keywords: Middle Passage, Charles Johnson, Erich Fromm, syndrome of decay, syndrome of growth, biophobic ethics, biophilic ethics

\section{Introduction}

Published in 1990, Middle Passage enabled Charles Johnson to become the second black winner of the National Book Award since Ralph Ellison won it in 1953, which is also the highest honor he has ever accepted till now. The book title alludes to one of the most inhuman things in the Western history, that is, the slave trade that began roughly in the 15th century and lasted for several hundred of years. During that time, a triangular trade route was set up among Europe, Western Africa, and America, while middle passage refers generally to the time of in-betweenness for those black slaves being traded from Africa to America. ${ }^{1}$

Because Johnson adopts a lot of postmodern narrative techniques in this fiction while deliberately relating

\footnotetext{
* Acknowledgement: This research is funded by the National Planning Office of Philosophy and Social Science of China (Reference 14CWW022), and by the China Postdoctoral Science Foundation (Reference 2014M552063).

JIA Yan-yan, M.A., lecturer, School of Foreign Language Education, Shandong University of Finance and Economics.

CHEN Hou-liang, Ph.D., associate professor, School of Foreign Languages and Literature, Shandong University of Finance and Economics.

${ }^{1}$ Matthew V. Johnson Sr. probes more deeply into the history of the Middle Passage and its traumatic impact upon the American black people (pp. 541-550).
} 
its stories to some historical realities, many critics take it typically as a postmodern historiographic metafiction. ${ }^{2}$ Mark Steinberg, for example, pays attention to "the ways in which the novel reflects, differs from, and comments on the slave narrative” (p. 377), and holds that the novel is a "postmodernist retelling of slave narrative” (p. 389). Similarly, Daniel Scott (1995) and Barbara Thaden (1997), after analyzing Johnson's parody and subversion of various classical literary texts, argue that Middle Passage affirms and questionizes the conceptions about race, identity, and freedom. Different from these studies, this article will read the novel from a Frommian perspective. In light of Erich Fromm's hypothetical but quite persuasive theory about human nature in The Heart of Man, the authors will follow with interesting two completely opposite systems of ethics for life appeared in the novel, that is, biophobic ethics and biophilic ethics, the former being embodied by Captain Falcon's "syndrome of decay" which is also Johnson's critical metaphor of Western civilization, while the latter embodied by the Allmuserial "syndrome of growth" which represents Johnson's idealistic imagination of the sum of non-Western civilization.

\section{Captain Falcon, “Syndrome of Decay”, and Biophobic Ethics}

Most of the story in Middle Passage took place aboard the Republic, a slave ship jointly owned by several unknown investors, the name of which alluded to the United States. Originally, it planned to set out from New Orleans and cross the whole Atlantic to arrive at Guinea in the west coast of Africa, where it would take a batch of black slaves belonging to a legendary ancient tribe called Allmuseri, and then it would make a return voyage within three months. Johnson deliberately creates a lot of symbols in the novel, thus making this voyage abound with intertextuality with many classical sea novels in the history of American literature. ${ }^{3}$

Captain Ebenezer Falcon was "a Faustian man of powerful loves, passions, hatreds: a creature of preposterous, volatile contradictions” (p. 49). In order to escape punishment for many felonies including murder and treason he committed, he chose a life of sea adventure and gradually became captain of Republic. Years of adventurous experiences molded him into an eccentric, arrogant, and paranoid solipsist. As a faithful believer of Nietzschean "will to power" and Darwinism, he looked the world from a very bleak ethical perspective: The world is a battlefield, the theme of which is oppression, plunder and conflict; since there is the only discrimination between the weak and the powerful, rather than between the good and the evil, the great Creator will not have the least sympathy with the humble inferior. Understandably, a believer of such amoral Weltanschauung was also a staunch supporter of slavery. To Rutherford he preached:

Conflict [...] is what it means to be conscious. Dualism is a bloody structure of the mind. Subject and object, perceiver and perceived, self and other-these ancient twins are built into the mind like the stem-piece of a merchantman. We cannot think without them, sir. [...] Mind was made for murder. Slavery, if you think this through... is the social correlate of a deeper, ontic wound. (Johnson, 2005, pp. 97-98)

In order to forge himself into a Nietzschean superman, both physically and spiritually, he adopted various exceptionally brutal trainings, which eventually helped him to achieve a lot of remarkable successes, and become a legendary empire hero, "[t]hat special breed of empire builder, explorer, and imperialist that sculptors loved to

\footnotetext{
${ }^{2}$ In Linda Hutcheon's definition, historiographic metafiction refers to "those well-known and popular novels which are both intensely self-reflexive and yet paradoxically also lay claims to historical events and personages” (p. 5). To know more aesthetic features of this kind of postmodern writing, see Hutcheon (1988, pp. 105-124).

${ }^{3}$ For example, Byrd (2005) and Nash (2003) have both interpreted the novel from comparative perspectives with Jack London's The Sea Wolf and Herman Melville's Moby Dick.
} 
elongate $[\ldots]$ in city park statues until they achieved Brobdingnagian proportions” (p. 29).

Falcon, the name itself alluding to the national emblem of the United States, characterizes a typical imperialist, who is most often downright moral nihilist and fanatical war hawk, and "whose burning passion was the manifest destiny of the United States to Americanize the entire planet” (p. 30). According to Erich Fromm, the cult of bellicosity and violence often results psychologically from the "syndrome of decay", which is "the most severe pathology and the root of the most vicious destructiveness and inhumanity” (p. 22), a kind of mental problem caused by three concurrent psychological diseases including "necrophilia (biophilia), narcissism and symbiotic fixation to mother"(p. 22), the fundamental pathogeny of which usually relates to the Oedipus Complex abnormally developed during childhood. This is exactly the case of Falcon. When he was a boy, he was very closely attached to his mother. Because his mother failed to get satisfied with her dull and apathetic husband, she casted all her energy and attention to the cultivation of her son: "[She] poured stories about El Dorado and the Fountain of Youth, her feelings and fantasies into Ebenezer. She placed maps before him, and music boxes; like most doting mothers of this sort, she lived vicariously through her son” (p. 49). Inevitably, too much unnaturally given maternal care had crucial impact upon young Falcon's psychology: "Falcon grew up determined to outperform his father (and most other men) and bring her gifts from all the lands she would never see” (p. 49). To please his mother with all his efforts was but a symptom of his ill-developed Oedipus Complex.

Fromm develops Freud's theory about the contradiction between Eros and destruction, or between the affinity to life and the affinity to death. Although he acknowledges these two affinities form "the most fundamental contradiction which exists in man” (p. 50), he refuses to regard the affinity to death as a biologically inherent instinct, and views it as a psychopathological phenomenon instead. He writes:

The life instinct thus constitutes the primary potentiality in man; the death instinct a secondary potentiality. The primary potentiality develops if the appropriate conditions for life are present, just as a seed grows only if the proper conditions of moisture, temperature, etc., are given. If the proper conditions are not present, the necrophilous tendencies will emerge and dominate the person. (Fromm, 1980, pp. 50-51)

Conditions beneficial to the cultivation of the life instinct include naturally a positive growing environment full of tender love and care, "to be with people who love life" (p. 51), while the conditions inclined to foster death instinct comprise "growing up among death-loving people; lack of stimulation; fright, conditions which make life routinized and uninteresting; mechanical order instead of one determined by direct and human relations among people" (p. 52).

Unfortunately, Falcon was brought up in such a death-instinct-friendly environment. His mother—“a pale, lonely women" (p. 49) - was very likely to be infatuated with the love of death. For short of communication and exchange of love with her husband, she lived in a very lifeless situation. According to Fromm, although a mother obsessed with the love of death will not do harm to her child directly, she is likely to stifle the child's interest in life, so as to infect him or her with the love of death, which will eventually result in the appearance of the syndrome of decay, such as necrophilia, violence, incest, narcissism, homosexuality, apathy, bloodthirstiness, eccentricity, sadism, and other abnormal behaviors. Almost all these symptoms can be easily observed from Falcon.

Firstly, he might be necrophilia, as he liked boasting of his experience of cannibalism, while Fromm tells readers that "[necrophiles] are those people who love to talk about sickness, about burials, about death" (p. 39). 
Secondly, he was a severe sadist. Because of his ruthless tyranny over the black slaves and crew, practically everyone aboard the Republic harbored bitter hatreds for him, and henceforward, both the white crew and the black slaves, intolerable with his despotic regime, planned to overthrow him. Thirdly, Falcon was very eccentric and lonely. "Few mates wanted to share his company" (p. 52). Most of the time, Falcon locked himself in his own narrow and dark cabin. Since he was suspicious of anybody, he laid a lot of traps in his room, and carried his dagger and pistol closely with him even when he was asleep. His excessive vigilance against attacks reminded readers of Fromm's caution that “as long as most of man's energy is taken up by the defense of his life against attacks, or to ward off starvation, love of life must be stunted, and necrophilia fostered” (p. 52). Fourthly, he was homosexual, inflicting poor Tom with all his sexual perversion. Since he was captain—or paternal protector in a sense - of the Republic, his sexual abuse with young Tom could also be interpreted as a variation of incest. Finally but most crucially, he was deeply obsessed with the love of death. Despite of all the exercises he had taken to anneal his surviving skills, and all the vigilance he always kept for self-protection, "he had the air of a man who desperately wanted to die” (p. 52). Just like Captain Ahab in Moby Dick, or Captain Larsen in The Sea Wolf, they all harbored such crazy ideas. As captain of the Republic, Falcon should be responsible for the survival of everyone aboard the ship. Regardless of his ethical responsibility, however, Falcon cared the least about the safety of others. In fact, most of the crew members sensed his crazy will to death, as the first mate Cringle warned Rutherfold:

Stay away from him, Rutherfold. He’s mad. And if you hope to see New Orleans again, the best thing is to separate yourself from Falcon now. [...] He will sink this ship and take us with him. He doesn't want to return. (Johnson, 2005, p. 62)

Fromm's observation that "the death instinct $[\ldots]$ has the function of separating and disintegrating" (p. 49) helps to account for the negative role Falcon took part during the voyage, that is, he was the root cause of all the conflicts and disunities among the crew. To ensure his control over the crew, his took a sinister strategy—-Divide and conquer. Poison each man's perception of the other” (p. 58). Far apart from the land, the Republic was like a society in miniature. All the crew members, despite of their different backgrounds, were expected to pull together in times of trouble. Only by working in unity and close cooperation could they overcome disease, starvation, rainstorm, and other hardships. With Falcon's vicious agitation, however, they became a fractured group harassed by mutual provocation:

[The] crew was perpetually angry and dissatisfied. What was odd in this was that it wasn't their anger at all-it was Falcon's. His emotions permeated the ship like the smell of rum and rotting wood, and these feelings_-as is always true of groups confined together in small quarters, or of couples - the men picked up, believing the directionless rage they felt to be their own. (Johnson, 2005, p. 53)

One more thing deserves to be mentioned. Since Falcon was characterized by Johnson as a typical imperialist, his "love of death" can be interpreted as a metaphor for the distinctive ethical features of modern Western civilization. It is in this sense that Johnson's critique against Falcon becomes more significant. Although the Western civilization has achieved marvelous material and technological successes since the 17th century, it fails to make as much achievement by the ethical standard. Because of its advocacy of virtues propitious to individualism, such as cruel law, free competition, natural selection, and ruthless violence, it would eventually 
end up in brutal racialism, colonialism, imperialism, and even Nazism, which, for Johnson, are but variations of “syndrome of decay”.

\section{Allmuseri, “Syndrome of Growth”, and Biophilic Ethics}

The Allmuseri slaves were a crucial community in this novel. It was under their influence that many crew members, including Rutherfold, Cringle, and Squibb, gradually gave up their ethics dominated by the love of death and completed spiritual transformations respectfully. It is worth mentioning that the Allmuseri people appeared in many of Johnson's works, such as the Swamp Women in Faith and the Good Thing (1974), the coffinmaker Reb in Oxherding Tale (1982), Chayn Smith in Dreamer: A Novel (1998), and many other characters in his short fictions as well. But in no other stories had they been given so much attention than in Middle Passage.

As Rushdy argues, the Allmuseri are not a real people, and "they exist only as a fictional product of Charles Johnson's fertile imagination” (p. 373). ${ }^{4}$ Although Johnson did not give readers a systematic introduction to this tribe, readers can infer its history and culture from Johnson's scattered descriptions in his books. The Allmuseri were a mysterious ancient tribe living on the West Coast of Africa. Rumors had it that "their palms were blank, bearing no lines. No fingerprints. All Allmuseri [...] had a second brain, a small one at the base of their spines” (p. 61). Besides of their physical strangeness, their minds and habits were even more distinctive from any other nations in this world. Johnson once remarked on the creation of the Allmuseri: "I just borrowed from different third world cultures to create a composite tribe that I wanted to be as non-Western in its values as possible” (Blue, 2004, p. 136). In other words, Johnson combines various merits and virtues that were enjoyed by many ancient-mostly Eastern and African — civilizations in the past but have been ignored by modern Western people, so as to reflect problems existing in modern Western society.

Eastern religions - chiefly Hinduism, Taoism, and Buddhism-can often be observed in the Allmuseri culture. Like the Buddhist, for example, the Allmuseri are opposed to dualism- "The failure to experience the unity of being everywhere was the Allmuseri vision of Hell” (p. 65). Oblivious of the division between subject and object, self and others, they refused to distinguish concrete things with abstract categories. Their language and logic were totally different from anyone readers have known:

Not really a language at all [...] as a melic way of breathing deep from the diaphragm that dovetailed articles into nouns, nouns into verbs. [...] [The] predication "is", which granted existence to anything, had over the ages eroded into merely an article of faith for them. Nouns or static substances hardly existed in their vocabulary at all. A "bed" was called a "resting”, a "robe" a "warming". [...] Their written language [...] was no less unusual [...] It consisted of pictograms. You had to look at the characters [...] as you would an old friend you've seen many times before, grasping the meaning — and the relation to other characters—in a single intuitive snap. (Johnson, 2005, pp. 77-78)

To judge from these descriptions, it can be argued that the Allmuseri mind had successfully escaped the Derridean logocentrism, as Rushdy rightly observes: “Their spoken language, then, is an ideal construction for intersubjective relations. [...] Their written language [...] is transcendent and embodies in every instance the preconditions of 'intersubjectivity and cross-cultural experience”” (p. 378).

The Allmuseri were also as ascetic as Hindus. Although Falcon gave them the most inhuman treatment, they

\footnotetext{
${ }^{4}$ Walby (1995) argues, however, that the Allmuseri "is an amalgamation of Bambara, Dogon, and Egyptian religion and mythology" (p. 658), rather than a totally fictional tribe.
} 
seldom rebelled. Furthermore, Taoism could be observed in their behavior. Despite of their physical slavery, they could remain their spiritual freedom. While in Oxherding Tale, the perfect artistic skill of Reb in making coffins reminds the reader of Woodworker Ch'ing in "Mastering Life" of Chuang Tzu, Johnson's characterization of Ngonyama alludes a lot to Cook Ting in "The Secret of Caring for Life" of Chuang Tzu. ${ }^{5}$

Being a most pacifist people, the Allmuseri were vegetarian, and they never killed animals, nor did they steal. They did not know what vanity was, and would not allow themselves to have the least possible conflict with others. It was said that "Allmuseri elders took twig brooms with them everywhere, sweeping the ground so as not to inadvertently step on creatures too small to see" (p. 78), which is an exact practice of Buddhist ethics. Arguably, Johnson's description of the Allmuseri is imbued with the idea of "interbeing", a key concept in Thick Nhat Hanh's Buddhist philosophy, ${ }^{6}$ which believes that nothing is isolated, and everything, including self and others, human and nature, animal and plant, life and nonlife, are all interconnected to form a unity (see Hanh, 1987, pp. 44-46; 1995, pp. 133-135), a belief drastically different with Falcon's dualism.

In contrast to Falcon's syndrome of decay, what readers observe with the Allmuseri can be diagnosed as the "syndrome of growth". According to Fromm, the syndrome of growth "consists of love of life (as against love of death), love of man (as against narcissism), and independence (as against symbiotic-incestuous fixation)” (p. 23), which results from the potential love of life being fully developed in suitable conditions. While those who love death is usually addicted to the ethically evil things such as violence and destruction, those who love life believe in the biophilic ethics— “Good is all that serves life; evil is all that serves death. Good is reverence for life, all that enhance life, growth, unfolding. Evil is all that stifles life, narrows it down, cuts it into pieces” (Fromm, 1980, p. 47). Devoid of hatred and against violence, the Allmuseri showed their respect to and sympathy with everything irrespective of living or nonliving things. Agape, if readers have to find a corresponding term in the Christian world, must be the best one that can summarize the essentials of the Allmuseri ethics. Actually, the author himself praises the Allmuseri as "the most spiritual tribe in the world, a whole tribe of Mother Theresas and Gandhis" (Rowell, 1997, p. 545).

The Allmuseri ethics was best embodied in their mysterious but all-mighty god. Johnson's description of the Allmuseri god resembles very much to a symbolic profile of Lao Tzu's Tao, as he writes,

[It] sustains everything in the universe. [...] It works, like a weaver [...] to ensure that galaxies push outward and particles smaller than the eye dance their endless, pointless reel. It is the heat in fire [...]. The wetness in water. (Johnson, 2005, p. 100) $)^{7}$

\footnotetext{
${ }^{5}$ In Johnson's description, Ngonyama's action when carving a pig is but an African version of Cook Ting's. He writes, for example, “Ngonyama began to carve. He slipped metal through meat as if it wasn’t there or, leastways, wasn't solid, without striking bone, [...] without hacking or rending—doing no harm—-the blade guided by [...] a knack [...], tracing the invisible trellis of muscles, tendons, tissues, until the pig fell apart magically in his hands” (p. 76). Compare it with Chuang Tzu's writing of Cook Ting: "Cook Ting was cutting up an ox for Lord Wen-hui. At every touch of his hand, every heave of his shoulder, every move of his feet, every thrust of his knee-zip! zoop! He slithered the knife along with a zing, and all was in perfect rhythm, as though he were performing the dance of the Mulberry Grove or keeping time to the Ching-shou music"(Chuang Tzu, ch. 3).

${ }^{6}$ As an admirer of Thick Nhat Hanh, Johnson thinks highly of the Vietnam Buddhist thinker's theory about "interbeing”, which has great influences over his writings. Although it is often understood as a synonym of intersubjectivity, it covers a wider range in connotation. See Thick Nhat Hanh (1987, pp. 44-46; 1995, pp.133-135).

7 Compare Johnson's description of the Allmuseri god with Lao Tzu’s description of Tao: “If you can talk about it, it ain’t Tao. If it has a name, it's just another thing. [...] You can't see Tao, but it's there. Damned if I know where it came from. It's just always been around. [...] Tao is like a bellows: It's empty, but it could help set the world on fire. Tao is an eternal mystery, and everything starts with Tao. [...] Tao never stops”(Lao Tzu, ch. 1).
} 
In fact, being at once natural and supernatural, it was totally beyond approach for the Western cognitive category sustained by dualism and essentialism, because, Falcon reluctantly acknowledged, "the Allmuseri god is everything, so the very knowing situation we mortals rely on—a separation between knower and known—never rises in its experience" (pp. 101-102). ${ }^{8}$

\section{Conditions Depressive to the Development of Life Instinct}

For some critics, the Allmuseri are just like a tribe from the wonderland, Johnson's illogical description of which downplays its significance. Steinberg points out that many of their behaviors are inconsistent with their culture and ethics (p. 379). There are stealing, murder, and suicide sometimes, for example. Furthermore, from Ngonyama's story about the tribe's history, it can be inferred that there were also scoundrels like Diamelo who was anything but pacifist. After the mutiny under the leadership of Diamelo, most of the Allmuseri changed drastically from idealist pacifists into ruthless killers. Out of crazy revenge for the oppression the crew had inflicted upon them, they became almost as dictatorial as Falcon used to be. They would have killed every white crew if not for Rutherfold's dissuasion. Is it tenable, then, for Nash to suggest that all these inconsistencies in Johnson's story show the author's suspect of "the unsustainability of their worldview" (p. 139)?

The answer is negative, of course. To begin with, the Allmuseri culture and ethics are represented by Johnson as the ultimate ideals, rather than as realities, and it necessarily does not imply that every individual of the tribe could achieve the idealistic standards. Moreover, the Allmuseri people's life instinct is completely depressed during the voyage, which is the root cause for their betrayal against their ethical ideals. From Fromm's viewpoint, three factors are prerequisite for the potential life instinct to fully develop in a society:

[1] Security in the sense that the basic material conditions for a dignified life are not threatened, [2] justice in the sense that nobody can be an end for the purposes of another, and [3] freedom in the sense that each man has the possibility to be an active and responsible member of society. (Fromm, 1980, pp. 52-53)

For the Allmuseri, however, none of the three factors can be found aboard the Republic. As fettered slaves, they were deprived of security, freedom, and justice, which inhibited the unfolding of their love of life while inducing the necrophilic tendencies, and eventually ended up in the riot.

Although the Allmuseri defeated the crew and took over the ship, it can hardly be claimed that they had won their freedom. Bloody killing had thoroughly stained their soul, making it impossible for them to maintain their original ethical ideals: "From the perspective of the Allmuseri, the Captain had made Ngonyama and his tribesmen as bloodthirsty as himself, thereby placing upon these people a shackle, a breach of virtue, far tighter than any chain of common steel” (p. 140). Filled with hatred in their heart, they had been actually bereaved of the unity of Being, and thrown into the hell dominated by dualism. Falcon was killed, but his syndrome of decay had infected many of the Allmuseri represented by Diamelo. Out of his crazy mind, Diamelo misfired the cannon and blasted the Republic, drowning nearly all the people aboard the ship except for Rutherfold, Squibb, and several orphans of the Allmuseri later to be adopted by Rutherfold. The tragic end of the Republic has its symbolic significance. It implies that if the oppressed, regardless of any cost, took their crazy revenge over the oppressor

\footnotetext{
${ }^{8}$ It seems unbelievable that such an all-mighty god could fall prey to Falcon. We need not feel annoyed with all the illogical points in Johnson's description of this god, however, since his aim is not historical realism, magic imagination by which to reflect and criticize modern Western culture and ethics.
} 
just in order to give vent to their anger and hatred, rather than to look for justice in a justified way, they would finally bring destructive disasters both for others and for themselves. The end of the Republic also hints obliquely at the fate of the United States, that is, its flourishing in the future would depend on whether it could remould its social structure to create the proper conditions for the development of life instinct: security, freedom, and justice.

\section{Love and Responsibility: Ethical Teachings From the Allmuseri}

The Allmuseri before the mutiny upheld the best ethics, the essence of which involved love and responsibility. As Fromm writes, "Eros has the function of binding, integrating, and uniting organisms to each other and cells within the organism” (p. 49). According to the Allmuseri conception of the world, there is no hierarchical discrimination among all lives which enjoy a harmonious unity. Every individual being is closely related to others, and that means everyone must be responsible for the well being of theirs. Obviously, the Allmuseri ethics is in discord with the Western ethics that gives priority to individualism and rivalry. During the voyage along the middle passage, however, almost every member of the crew received positive influences upon their ethical conceptions from the Allmuseri.

In Rutherfold's narration, readers are told that all the crew, similar to himself, were "all refugees from responsibility” (p. 40). Squibb, for example, was a profligate who did not know for sure how many times he had been married, and how many wives he had betrayed. Meadows, though seemingly honest and coward, was an escaped convict who had murdered his whole family. After close contact with the Allmuseri during the voyage, however, these corrupted men witnessed their moral promotion gradually. Increasingly concerned with the safety and well-being of others, they began to take altruistic actions. Meadows, out of his free will, did the laundry for the crew and even for the slaves, while Squibb, after most of the crew were killed during the mutiny, metamorphosed into an altruistic model:

If asked to double-breech the lower decks or batten hatchways, he quietly did so, lifting himself above likes and dislikes, dwelling on the smallest details of his chores to deflect his mind from brooding - a Way, perhaps, to solder that deep schism Falcon believed bifurcated Mind. (Johnson, 2005, pp. 175-176)

With his altruistic performance of whatever required him to do, Squibb became a model figure morally purified, which perhaps accounted for his survival at the end of the story.

Compared with Squibb's moral change, the awakening of Rutherfold's ethical consciousness constitutes the central plot of the novel. In the beginning, Rutherfold was a cynical slacker escaping his familial and social responsibilities. Out of the humiliation and victimization he imaginatively felt for being abandoned by his run-away father, he vented his anger and hatred on every living thing on this world, unfairly blaming them —and mostly his father-for depriving him of happiness he should have enjoyed. Arguably, the young Rutherfold, similar to Falcon, was also harassed by the syndrome of decay, which eroded his capability to give love to and take responsibility for others. When he finally fell in love with Isadora, however, he ran away for fear of the ethical responsibilities that might be involved after marriage. During the early period of the voyage, he took advantage of his identity as an outsider aboard the ship and enjoyed his vantage point where he could deceive anybody for his own benefits while not being ethically responsible to any others. After he gradually got familiarized with the Allmuseri, and especially with their language and culture, however, readers observe the unintended but remarkable ethical transformation that took place with Rutherfold. 
First of all, he became fully aware of his ethical responsibility towards others around him. As he realized:

During each crisis, every action had to be aimed at helping your fellow crewmen. You could not afford to tire. Your duty was always to insinew your ship; if you hoped to see shore, you must devote yourself to the welfare of everyone, and never complain, and constantly guard against showing weakness. (Johnson, 2005, pp. 186-187)

In other words, living in the world is just like sailing on the sea, which means that the fates of everyone are closely intermingled, and only concerted efforts and mutual responsibilities could guarantee their survival and well being.

Secondly, he learned from the Allmuseri what love, sacrifice, and patience mean, and how to understand life and duty from an ethically more enlightened point of view. In his words,

...the voyage had irreversibly changed my seeing, made of me a cultural mongrel, and transformed the world into a fleeting shadow play I felt no need to possess or dominate, only appreciate in the ever extended present. Colors had been more vivid at sea, water wetter, ice colder. (Johnson, 2005, p. 187)

Liberated from the limitation of dualistic thinking, Rutherfold finally achieved his moksha as Andrew Hawkins did in Oxherding Tale, both in a sense resembling those enlightened Buddhists or Taoists who refuse to discriminate among things and could "make all things equal” (Zhuang Tzu, n.p.) so as to be free from the worry of making illusory choices. Before the voyage, Rutherfold had been a prisoner of his own sensual desires, which drove himself into an endless hunt for beautiful women, gorgeous clothes, and unscrupulous activities, but after his enlightenment, he found he had lost his interest in these things: "[...] I simply could not do this now. none of it made sense after the Middle passage” (p. 188).

Lastly, but crucially, Rutherfold had ethically transformed himself from a cynical slacker to a dutiful good father by adopting the several Allmuseri orphans and giving them his meticulous care. After the mutiny, the Republic lost its orientation, while disease, hunger, and thirst drove those survivors nearly to despair, but Rutherfold turned into a Mother-Theresas-like figure and looked after every one with patience. Neglecting his own pains, he alleviated the hurt for the injured, helped the terrified children to sleep with stories, and encouraged the people to hold on with jokes and white lies. He had totally succumbed the feeling of victimization and uselessness, and he felt full of the power of love now.

\section{References}

Blue, M. (2004). An Interview with Charles Johnson. In J. McWilliams (Ed.), Passing the Three Gates: Interviews with Charles Johnson (pp. 123-141). Seattle: University of Washington Press.

Byrd, R. (2005). Charles Johnson's novels: Writing the American palimpsest. Bloomington: Indiana University Press.

Chuang, T. (2014). The complete works of Chuang Tzu. Retrieved August 20, 2014, from http://www.taoiststudy.com/content/complete-works-chuang-tzu-translated-burton-watson

Fromm, E. (1980). The heart of man: Its genius for good and evil. New York: Harper Colophon Books.

Hanh, T. N. (1987). Being peace. Berkeley: Parallax Press.

Hanh, T. N. (1995). Living Buddha, Living Christ. New York: Riverhead Books.

Hutcheon, L. (1988). A poetics of postmodernism: History, theory, fiction. New York: Routledge.

Johnson, C. (2005). Middle Passage. New York: Scribner.

Johnson, M. V. (2005). The middle passage, trauma and the tragic re-imagination of African American theology. Pastoral Psychology, 6(53), 541-561.

Lao Tzu. (2014). The Tao Te Ching by Lao Tzu-Adapted by Ron Hogan originally attributed to Jesse Garon. Retrieved August 20, 2014, from http://www.taoiststudy.com/content/tao-te-ching-lao-tzu-adapted-ron-hogan-originally-attributed-jesse-garon 
Nash, W. (2003). Charles Johnson's fiction. Urbana: University of Illinois Press.

Rowell, C. (1997). An Interview with Charles Johnson. Callaloo, 3(20), 531-47.

Rushdy, A. (1992). The phenomenology of the Allmuseri: Charles Johnson and the subject of the narrative of slavery. African American Review, 3(26), 373-94.

Scott, D. (1995). Interrogating identity: Appropriation and transformation in Middle Passage. African American Review, 4(29), 645-55.

Thaden, B. Z. (1997). Charles Johnson's Middle passage as historiographic metafiction. College English, 7(59), 753-66.

Walby, C. (1995). The African sacrificial kingship ritual and Johnson’s middle passage. African American Review, 4(29), 657-69. 